\title{
Architecture of the South of Russia in the National Culture and the National Space
}

\author{
Andrey Bokov \\ Scientific Research Institute of Theory and History of Architecture and Urban Planning \\ Branch of the Central Institute for Research and Design of the Ministry of Construction and Housing and Communal Services of \\ the Russian Federation \\ Moscow, Russia \\ sarrus@rambler.ru
}

\begin{abstract}
The article analyzes the historical and cultural background of South Russia's special architectural and artistic image formation. Natural and climatic conditions of the southern Russian sub-region are unique and have identified its architecture and place in mind and culture. The South is a treasure, close by its characteristics to an idealized GrecoRoman world. In contrast to the Central, Northern, Western and Eastern sub-regions, the Southern region is marked by a consistently positive attitude, raised by Russian literature and art of the XIX-XX-th century. This makes the South of Russia potentially the most attractive and natural "space of growth and development," a laboratory of practices relevant to the whole country.
\end{abstract}

Keywords-architecture; urban planning; artistic image; cultural landscape; antique; national culture; national space; living environment

\section{INTRODUCTION}

Of the 13 million $\mathrm{km} 2$ belonging to Russia, only 3 million $\mathrm{km} 2$ can be referred to as the "oecumene", i.e. the territory supporting safe, comfortable, and successful life. The Mankind proved that it can survive in the Arctic, on the Moon, underwater, etc. by creating special artificial environment that is suitable not so much for living as for surviving. The "oecumene" does not suppose or require any extraordinary efforts due to its compliance with standards that were determined through trial and error. These standards can be described as a complex of balanced environmental and climatic indicators, which can be studied and finessed infinitely [1]. More importantly, this standard imprints itself in the system of culture, and acquires the form of an integrate, syncretic worldview. We inherited the most part of this view from the Antiquity, in which the civilized and the barbarian worlds were separated. The borders of the Roman Empire reached the Danube; everything that lied to the Northeast, where olives and grapes did not grow, where there was no oil and wine, was called "Hyperborea" and drew no interest. Roads were never built there, there were no Roman camps or cities. This view and the system of values were inherited not only by those who conquered the Antique world, but also by the inhabitants of the "hyperboreas". The world of the Western and Eastern Empires not only became a compelling alternative to the cold and severe world of Germanic and
Slavic peoples, but also their unique and sustainable version of the "heaven on Earth".

Germanic peoples were lucky enough to have a unique opportunity to create their own Rome from the Antique material almost in the same place. Due to their efforts, thousands years after Western-European centers adopted decorations clearly reminding the Antique prototypes. Luckily, those were everywhere around. The magnetism of the Antiquity, the persistence of ideas that brought forth Renaissance and Classicism with all their branches and variations proved to be so strong that the efforts of Western Europeans brought "pro-Roman" decorations everywhere in the world, from America to Australia.

The inhabitants of the vast territories to the North and East of Mediterranean, who witnessed the Antique and PostAntique worlds only during invasions and leant about them form other people's stories, had nothing to do but to dream of the heaven on earth and somehow to recreate it far away from the "oecumene", on their soil with no olive groves or vineyards.

The first victims of the culture shock from the communication with the Post-Antique Byzantium were those who travelled along the trade route from Scandinavia to the Byzantine Empire ("from the Varangians to the Greeks"). It is characteristic that the cultural trend that changed during the Mongol invasion, switched to making Moscow the "Third Rome" following the decline of the Golden Horde influence. It meant the formation of a special system of goals and values or a "national idea" defining the geopolitical strategy as well as ordinary life. Following these sentiments, during the imperial era, Petersburg - the city of Peter challenges the Christian Rome. The desire to bring North the antique clothes and architectural decorations remained among the Russian elite both in the imperial and the Soviet times.

The attempts to create Rome in the North easily switched to the direct expansion to the South, towards the antique "oecumene", Caucasus and Crimea, the closest to Russia shores of the Antique and Post-Antique world. Catherine II's wars for the Black Sea region and Crimea, the resettlement of Cossacks from Zaporizhia to Kuban, the defence of 
Sevastopol and the fight for the Caucasus under Nicholas I were only a prelude to the major imperial project to obtain the Straights and Constantinople. The project to put the cross on top of St. Sophia failed. Alexander II's and Nicholas II's endeavours were fruitless, but the antique dream never disappeared from the antique discourse [2].

In Stalin's USSR, this dream transformed and received a new outline. Ethnic cleansings and forced resettlement of entire peoples were carried out simultaneously with the establishment of the idea of the Soviet paradise, a space of sanatoriums and palaces for the people, miners, farmers and steelworkers. The most venerated dwellers of this paradise were children, who were given the legendary summer camp Artek. The Olympic Sochi and the acquisition of Crimea remain today's dominant topics with a tint of excitement and exaltation and incomparable in popularity with anything in the latest Russian history. The dream of the South is not only alive, but is also easily actualized. It captivates all strata of the Russian society and is more and more associated with the national idea not only despite, but also due to its obvious imperial spirit.

\section{PERCEPTION OF THE SOUTH: SOUTH IN THE RUSSIAN CULTURE}

In the mass, public consciousness the national space, the space of the country is structured on the basis of a most simple archetypical model, in which there is the center - or the central region - and "subregions" - northern, eastern and southern. Each of the subregions is perceived and evaluated in its own way. Russian North is a space of survival and endurance, a space of permanent anticipation of light and warmth. The East, the Siberia is a new, unsettling, sparsely populated infinite and, at the same time, closed, with complicated reputation and origin. The West is a space generating dangers, carrying the memory of turmoil and tragedy. And only thinking of the South, we experience pleasant feelings. The image of the South, the myth of the South being the Promised Land, the space of joy, harmony, freedom and justice celebrated, first of all, by the great Russian literature. Pushkin, Lermontov, Tolstoy, and after them Sholokhov, Kuprin, Grin, Bagritsky, and finally Aksyonov and Iskander, all of them agreed in their special, gentle attitude to the South. The South becomes the background for the most loved, positive Soviet comedies from the Jolly Fellows and the Cossacks of the Kuban to the Kidnapping, Caucasian Style and the Diamond Arm.

This mythology was grounded in the real wellbeing of the South even during the most severe political cataclysms and economic disasters. The South never experienced the famine that devastated Central Russia. The economic diversity that continued to exist even during Soviet time combine with the fertility of the soil and the hard-working nature of people provided a relative stability of the economy. Created by common efforts, the image of the Russian South resembles the image of the American Wild West as a special space that significantly differs from the center and the places ruled by tradition, canonicity and the almighty bureaucracy. South is a space of freedom, new and open, devoid of strict borders. The sea, so uncommon for most Russians, the shores of which are so vast in the South, a straight road to the big outside world, and the South itself present us with many discoveries. Unlike the Centre, it is rich and generous, bright and fertile, has many cultural layers, the traces of which have a magical, mesmerizing influence on the people from the Russian Plain.

\section{HERO OF THE SOUTH}

The dweller of the South, real and fictional, is a true Hero: active, free, and independent. He is the direct opposition to the miserable, suffering, burdened by conventionalities "small man" suppressed by the capital and enslaved by the province.

The Sough gives opportunities and wakes up hopes: this is a world of an individual, not a community. It' most famous inhabitants were the Cossacks, who came from the North. In no time the Cossacks absorbed blood and customs of their new neighbors and enemies. They played the most active role in the formation of the southern sub-ethnicity. The original ethnic diversity of the South resulted in the emergence of a unique Southern Russian community with its own language, facial type, temper, and behavioral stereotypes [3]. This community was formed not so much on blood relationship as on lifestyle, which was very similar to what was happening in the USA at the same time. The inhabitants of the South of Russia shared the following. They never depended too much on the state and bureaucracy, they never knew serfdom and agrarian communities. The nature and the climate let the hardworking and responsible people survive without support from landlords and the community.

These characteristics of South Russian sub-ethnicity allowed the Stolypin's reform to go much smoother and made the South the backbone of the White movement during the Civil war.

The experience of self-governance and self-organization acquired in the course of two centuries based on negotiation as opposed to subordination and indisputable dependency led not only to a certain lifestyle, but also formed a specific world-view and "human resources". The "senseless and ruthless" Russian riot kindled and smouldered in the South. In was the South, where Russian criminal subculture, which exists today, acquired its language, poetics, ethics, and aesthetics, its leaders and heroes. The few adventurous characters of Russian literature, from Pechorin to Ostap Bender, are active, natural, and successful only in the South. The few recent protest rallies, where participants speak out for their rights, defend their personal interests, are organized by Kuban farmers and North Caucasian long-distance truck drivers.

\section{DIFFERENT SPACE}

The natural landscape of the South is different from and is characterized by an exceptional diversity. Winter Olympics in subtropical Sochi is a vivid illustration of such diversity. Mountains, hills, steppes and forests, mixed and compressed in a limited space along the long and winding seashore, gave birth to a fabulous living activity and a 
multifunctional and diversified economy. The cultural landscape of the South is as unique as the nature. There is no capital, no largest city, as well as the second and the third important cities, no strict hierarchy of settlements or stratification that appeared in Central Russia. Each settlement of the South is remarkable in its own way, no matter how big it is. There is a system of competing cities with different specializations. Those cities with adjoining territories form something reminding the antique system of poleis of the Aegean Sea area. Before 1917, the export of Russian hard wheat went through Taganrog, a city surrounded by wheat fields, which gave its name to the sorts of wheat that were used in Italia for making the famous pasta.

With the goods, coming from the opposite direction, new technologies came, which not as much stimulated the development of heavy industry as the "human capital". From early 19th century, Russian South becomes a place for recreation and treatment, incorporating all the signature features of Mediterranean and European cultures. Foreign and Russian architects, engineers and scientists, crop breeders and doctors, invited by local elites, effectively transformed the South, making it more and more popular and attractive. Wineries, mineral waters, mud baths, pools, restaurants, hotels, resort halls formed a huge industry that was vigorously reformed during the Soviet era [4]. This industry is intensively developing today by further reclamation of the Black Sea shoreline, creation of new skiing resorts, new tourist centers and routes.

The resort infrastructure, which has a network-based, disperse structure consists of relatively autonomous compact units, naturally integrates into the existing polycentric tissue of southern settlement system.

Both resting and living in the South are marked by a common feature defined by the environment: the obviously "disurbanistic" character, relatively low density, disjoined housing, open spaces, abundance of parks and gardens. Both tourists and locals choose neither urban nor rural, but some intermediate lifestyle. The development material itself is quite similar to the development material in Florida, as it is also represented by two contrasting groups or types. The multistoried hotels and apartments that were built by Soviet developers contrast with the low-rise development of the private housing sector. An own house with a yard, an estatehouse, remained in the South despite all the efforts of the Soviet administration and today's developers. It is the most popular and preferable type of dwelling [5]. The majority of people, who live in apartment blocks, are not advocates of urban life: they or their relatives own summerhouses or land lots for gardening.

\section{CONCLUSION}

The South was one of the biggest projects of the Russian Empire. One of the most famous forms of demonstration was, one of the versions of this project by Catherine II and the Austrian emperor, were the famous Potemkin villages. Contrary to the popular opinion that these villages were fraud and deception, it is possible to view them as a unique show on the topic of the happy future of recently conquered territories, a visible concept of reclamation and development. The contemporary South needs a development strategy as much as it did 200 years ago. The development of the region with a reputation of a "granary" and a "sanatorium" is very important for the destiny of Russian space as a whole. St.Petersburg and Moscow agglomerations and the South are the territories of sustained and progressive growth, forming the main directions of internal Russian migration. The South is successful and attractive; there are no depressive singleindustry cities, depopulated villages, or vast areas of hard-tocontrol high-rise apartment blocks.

While the capital mainly attracts young people, who pursue money and education, the South is a dream for retired military personnel, well-off pensioners, and people from eastern and northern regions. This spontaneous and uncontrollable flow of successful people, who wish for a quiet life or a new life and a new career, comes in parallel with another flow - season tourists. And while the spatial prospects of both capitals are topic for active discussion and concern, the space of the Southern sub-region as a unity never draws much attention. Meanwhile, the South can produce - and already does - an effective network-based dispersed system of settlements, similar to the ones in the EU, US, and China. The most important characteristic of these systems is the communication framework providing an intensive interaction of settlements, impeding the chaotic sprawling of settlements and the growth of continuous dense housing spots.

The most important and new for Russia characteristic of southern settlements could be the active participation of people, who, unlike many of their compatriots, preserved the inclination for self-governance and cooperation, in administration.

Today's South is an arena for the ongoing battle between large businesses - agricultural holdings and hotel networks small businesses, which generally lost the battle in other parts of Russia. Preservation of farms, service sector and resort businesses is natural for the South. The South needs "craft industry", small companies, flexible and adaptable to changes in the demand. Family businesses could act as a damper, compensator of seasonal fluctuations caused by the beginning and the end of tourist season.

People of the South never lost their ties with the land. Unlike their compatriots, who used communal fields, they still value their own land. This should be the starting point for the emergence and development of ideas and technologies that are usually called "green" and that fail to find support among large businesses and development monopolists. "Organic" food, local building materials, organized and well-equipped construction by people's own hands, development of local road networks, new means of transportation, use of renewable energy sources, production of biofuel, productive waste recycling. All of these something very well known, but difficultly accepted in Russia - should be implemented in the South. A targeted effective state support, people's desire to have their own house and yard will bring us a new type of settlements, new "garden cities", South-Russian "suburbia", which is not a 
surrounding of big cities with their huge apartment blocks, not foam accompanying a big city, but a self-sufficient phenomenon. A giant village, giant suburbanized territory with individual homes today is not a subject of reflection, not an area with rules and regulations, with architectural projects and expertise. Recognition, development, reorganization, renovation of this living, natural, growing tissue should define the contents of the manifest, first, of the South, and then, for the rest of Russia.

\section{REFERENCES}

[1] B. B. Rodoman, Territorial areal and networks. Essays on theoretical geography. Smolensk, Oykumena, 1999.

[2] M. V. Nashchokina, Antique heritage of the Russian architecture of the Nikolaev time. The analysis and creative interpretation. Moscow, Progress-Traditsiya, 2011.

[3] G. V. Esaulov, The architecture of the south of Russia. From history to modern times. Moscow, Arhitektura-S, 2016.

[4] A. A. Voronov, Mihaylova M. B. Cimmerian Bosporus. Moscow, Iskusstvo, 1983.

[5] L. Glazychev, City without borders. Moscow, Territoriya Budushchego, 2011. 